\title{
ACADEMIC PLAGIARISM AS THE INFRINGEMENT OF THE AUTHOR'S INTERESTS: NOTIONS, FEATURES AND TYPES
}

Chepys O. I.

This article focuses on the essential (intrinsic) nature, functional characteristics and types of plagiarism. There have been studied the key features of plagiarism distinguishing it from other infringements of intellectual property rights, in particular, piracy: plagiarism is always an infringement on a copyright object; in case of plagiarizing the authorship is always ascribed to a person who has not written the work (it is manifested through publishing someone else's work under one's own name); plagiarism is revealed only in the active action, whose form is determined by the legislator as the publishing of the work (making it public) either fully or partially. Academic plagiarism - publication (partially or completely) of the scientific findings, as if they were the result of your own research, however, they were, in fact, obtained by others, and/or the copying of the published texts written by other authors without the appropriate citing. There have been analyzed such types of plagiarism as self-plagiarism, reverse plagiarism, scientific plagiarism, pupil plagiarism and student plagiarism, rewriting, mosaic plagiarism, replication, contamination and abstracting. By levels (they differ on the basis of what is ascribed) plagiarism is reduced to five major modifications, which can be applied both to the intellectual (academic) and to the creative (artistic) spheres: the level of idea (concept); the level of structure (organization) of the text; the level of the title; the level of the material on which the text is based; the level of terminology. Particular attention is also paid to the distinction between plagiarism and other similar phenomena, in particular: appropriation, fanfiction, translation (adaptation) and borrowing. It is evident that creativity, particularly, scientific creativity, is an area that is difficult to regulate or limit. Nevertheless, the author in these relations is the key figure who not only enjoys the legal protection of his/her rights (including the right to acknowledge his/her authorship, the right to maintain the integrity of the work, etc.), but also deserves respect from society and its individual members, which is manifested, among other things, in the fair and lawful use of his works.

Key words: plagiarism, self-plagiarism, reverse plagiarism, appropriation, fanfiction, translation, borrowing, rewriting, replication, contamination, abstracting, interests.

у пропонованій статmі аналізуються сутнісна природа, функціональні характеристики й різновиди плагіату. Проаналізовано ключові ознаки плагіату, що відрізняють його від інших порушень прав інтелектуальної власності, зокрема від піратства. Досліджено такі різновиди плагіату, як самоплагіат, контрплагіат, науковий, студентський, учнівський плагіати, рерайт, мозайчний плагіат, реплікація, контамінація та реферування. Особливу увагу приділено також розмежуванню плагіату й інших подібних явищ, зокрема апропріації, фанфікшона, перекладення та запозичення.

Ключові слова: плагіат, самоплагіат, контрпла гіат, anропріація, фанфікшн, перекладення, запозичення, рерайт, реплікація, контамінація, реферування, інтереси.

Chepys O. I., 2019
В предлагаемой статье анализируются сущностная природа, функциональные характеристики и виды плагиата. Проанализированы ключевые признаки плагиата, отличающие его от других нарушений прав интеллектуальной собственности, в частности от пиратства. Исследованы такие разновидности плагиата, как самоплагиат, контрплагиат, научный, студенческий и ученический плагиаты, рерайт, мозаичный плагиат, репликация, контаминация и реферирование. Особое внимание уделено также разграничению плагиата и других подобных явлений, в частности апроприации, фанфикшена, переложения и заимствования.

Ключевые слова: плагиат, самоплагиат, контрплагиат, апроприация, фанфикшен, переложение, заимствование, рерайт, репликация, контаминация, реферирование, интересы.

To steal ideas from one person is plagiarism; to steal from many is research. Arthur Bloch's “Murphy's Law”

Problem statement. Plagiarism as an infringement of an author's rights is not a new phenomenon, but in the age of globalization, it has grown to tremendous proportions and become a real disaster. Although the Law of Ukraine "On Education" has enshrined the key provisions on academic integrity, cases of its violation and academic responsibility, today there are numerous instances of academic plagiarism. The systematic analysis of the essence of academic plagiarism as a violation of academic integrity will make it possible to understand the causes of the spread of this extremely negative phenomenon from a moral and ethical points of view.

The current developments in the research. The problem of preserving and protecting intellectual property rights against plagiarism was explored by such scholars as: T.M. Vakhonieva, N.P. Baadzhy, Ye.M. Bereznytsky, O.V. Zhylinkova, O.V. Kokhanovska, O.A. Kuznietsova, O.O. Mazina, O.M. Melnyk, M.O. Mints, O.P. Orliuk, O.O. Pidopryhora, O.V. Pikhurets, O.S. Ryzhko, T.V. Symonenko, K.L. Sopova, H.O. Ulianova, O.I. Kharytonova, R.B. Shyshka, O.O. Shtefan et al. Among foreign researchers there are: N. Adkhikari, L.O. Alokhina, T.V. Barchunova, O.R. Demidova, I.F. Zahorchev, S.S. Koburov, K. Kolberh, K.V. Kuznietsov, T.H. Liepina, V.O. Rassudovsky, R. Sibers, N.H. Tolochkova, M.L. Firsov, J. Noll, T.O. Yakusheva and others.

Results and discussion. The Law of Ukraine "On Higher Education" speaks of only one kind of plagiarism - academic plagiarism. It is the publication (partially or completely) of the scientific findings, as if they were the result of your own research, however, they were, in fact, obtained by others, and/or the copying of the published texts written by other authors without the appropriate citing [1]. 


\section{Проблеми цивільного та господарського права}

Its main feature is functioning in the academic, i. e. scientific and educational sphere. In the Regulations on Academic Plagiarism the state higher educational establishment "The Ukrainian Academy of Banking of the National Bank of Ukraine" views plagiarism as the intentional copying by a teacher, postdoctoral student, PhD student or student in a written or electronic form of another person's work, which was released in hard copy form or officially made public in the electronic version, fully or partially, under his/her own name without referring to the original author [2, p. 229-230]. Thus, there are two ways of academic plagiarizing: first, the publication (in part or in full) of the scientific results, obtained by others, as if these were the results of your own research; secondly, the reproduction of other authors' published texts without mentioning the original source. Academic plagiarism can be committed by either one person or a scientific team and the scientific result can be used in full or in part [2, p. 230].

The Law of Ukraine "On Education" also speaks of self-plagiarism [3]. Self-plagiarism in the scientific field is viewed as the republication by the author of scientific texts, which are significant in size and identical (or very similar) in the form and content, without indicating that these texts have already been published before (or published at the same time). It may be the republishing of the same article with minor changes in the title and content (duplicate (multiple) publication), or the publishing of an article containing vast excerpts from the previously published works without citing the source ("cutting") [4].

It is also considered to be an act of plagiarizing to use the work only under your own name in the case of joint indivisible co-authorship.

The type of plagiarism, which is interesting but scarcely explored, is reverse plagiarism. It is when a work, whose authentic author is unknown, is ascribed by third parties to a specific person who has no relation to this work. Reverse plagiarism became particularly popular in the Middle Ages. As a result, the problem of authorship of certain Old Testament books, canonical and apocryphal gospels causes difficulties for historians of religion. Perhaps the most famous example of reverse plagiarism is "Areopagatica", a collection of four tractates and ten letters devoted to theological topics, ascribed by an unknown thinker of the V-VI century, to the holy martyr Dionysius the Areopagite. That is why the author is referred to as Pseudo-Dionysius [5, p. 49].

In general, plagiarism can be classified by different criteria:

1) depending on the plagiarist, plagiarism can be divided into the following types: a) scientific plagiarism is plagiarism committed by researchers, academics, teachers, staff of research institutes, while writing scientific papers, textbooks, theses for obtaining a scientific degree; b) student plagiarism is plagiarism committed by students while writing course papers, diploma and master's theses, preparing the talking points for scientific conferences, round tables, etc.; c) pupil plagiarism is plagiarism committed by pupils. It seems that the prevention of pupil plagiarism should be at the forefront of activities aimed at reducing the level of plagiarism in research works. After all, irresponsible and disrespectful attitude towards writing scientific works, the results of someone else's creative intellectual activity, which starts from school, becomes the norm in the future; d) creative plagiarism is plagiarism that manifests itself in literary, artistic, musical works, etc. [6, p. 126]; 5) industrial plagiarism (in particular in the fashion industry, the field of engineering, design, etc.);

2 ) by levels (they differ on the basis of what is ascribed) plagiarism is reduced to five major modifications, which can be applied both to the intellectual (academic) and to the creative (artistic) spheres. They are presented in the format "from general to specific": a) the level of idea (concept); b) the level of structure (organization) of the text; c) the level of the title; d) the level of the material on which the text is based; e) the level of terminology [7, p. 94];

3 ) depending on the ways of committing, plagiarism is divided into: a) rewriting. O. Kuznietsova thinks: "This is hidden plagiarism... In the rewrite, the key, essential words remain untouched. Rewriters change the form of the text, but the essence of the information remains unchanged" [8, p. 24]. I. Lytvynchuk describes it as superficial [9] editing: "Making minor edits in the copied material (the reformulation of sentences, changing the word order in them, etc.) and without adequate referencing". That is, both of them talk about changing the architectonics of the text [10, p. 470-471]; b) mosaic plagiarism. It is the use of material from multiple sources and the rephrasing of certain words. The result is a kind of mosaic in which it is not clear where the citation ends and the author's opinion begins, or where one author's opinion ends and another author's opinion starts. Some authors call such plagiarism a compilation or intellectual plagiarism; c) contamination or "gluing" your text from fragments of other people's works without significant changes that would allow considering the "new" text, received as a result of this mechanical procedure, as copyrighted, and yet without referring to the authentic author/authors. This kind of plagiarism is similar to the mosaic one, but it is characterized by a greater degree of "mechanicality". In English this technique is called "cut and paste"; d) abstracting (rephrasing parts of the text of other authors by changing the word order or imitating the structure of their argumentation along with the reduction of the text without referring to the source) [7, p. 95]; e) the publishing of a work written by $a$ third party at the request of a student or teacher; f) copying other students' written works or homework (this is also plagiarism!); g) replication (it is the process of copying data from one source and disseminating it to many others, that is, a kind of "transmitting" information without the author's permission).

In order to thoroughly explore the nature of plagiarism, it is necessary to analyze the common and distinctive features of this category along with the related categories and notions. But before that we consider it necessary to point out the key features of plagiarism: 1) plagiarism is always an infringement on a copyright object; 2 ) in case of plagiarizing the authorship is always ascribed to a person who has not written the work (it is manifested through publishing someone else's work under one's own name). Therefore, if this is not identified, the misuse, publishing, copying, etc. of a copyrighted work is viewed as piracy, not plagiarism [11. p. 368]; 3) plagiarism is revealed only in the active action, whose form is determined by the legislator as the publishing of the work (making it public) either fully or partially [12, p. 21-23].

So, how can plagiarism be distinguished from similar phenomena? Let us try to make it clear. 
Plagiarism and appropriation. Here, the boundary is the thinnest and most blurred. According to Ye. Bereznytsky, appropriation is the most commonly used method in contemporary art. Artists borrow images from popular advertisements, the media, the works of other artists and use them in their own works [13, p. 253]. Appropriators seek to express their own ideas with the help of borrowed elements [14]. Appropriation is not simply the borrowing of another's work (or a part of it), but the expression of the new content, concept, idea with its help. It is clear that in view of these criteria disputes are inevitable, because the presence or absence of a certain idea in the work is in itself an ambiguous question [15]. The difference between appropriation and plagiarism lies in the purpose of the artistic borrowing and ways of using the borrowed fragments. For example, Henri Matisse took the idea from Ch. Ed. Boutibonne's painting "Sirens" and turned it into a completely different work, both stylistically and at the level of perception (see Charles-Edouard Boutibonne "Sirens" (1883) and Henri Matisse's "Dance" (1910)). It can in no way be viewed as plagiarism, though the idea is certainly borrowed.

Plagiarism and fanfiction. Fanfiction is the activity of fans of famous works, in which the very character is borrowed, with whose participation new works are created [6, p. 78]. A vivid example is a huge number of fanfics based on the the Harry Potter books. When creating fan fiction, the original work is used openly.

Plagiarism and borrowing. Borrowing is one of the forms of non-contractual use of another's work permitted by law when it is not necessary to obtain the author's consent, to pay him any additional remuneration, but the author's surname and the source of borrowing must be indicated. It is the latter condition that distinguishes borrowing from other forms of non-contractual use of works which are objects of copyright [16, p. 54]. Another condition for borrowing to be seen as lawful is the use of someone else's work in an amount justified by the intended purpose.

Plagiarism and translation (adaptation). Adaptation is viewed as using the ready copyright material for another type of performing. An example of this can be an opera score clavier, when all orchestral material is adapted to be performed on the piano. In this case, the author of the original work must be mentioned.

It is evident that creativity, particularly, scientific creativity, is an area that is difficult to regulate or limit. Moreover, any boundaries will not contribute to its development. Therefore, in this respect compromises should be sought. Nevertheless, the author in these relations is the key figure who not only enjoys the legal protection of his/her rights (including the right to acknowledge his/her authorship, the right to maintain the integrity of the work, etc.), but also deserves respect from society and its individual members, which is manifested, among other things, in the fair and lawful use of his works.

As a conclusion, I would like to cite the Russian researcher O. R. Demidova: "It turns out that "the answer to the question "to be or not to be? " depends on the answer to the question "to steal or not to steal?". "The death of the author" threatens to turn into "the death of science". However, the threat of an epidemic spread of plagiarism as a form of "co-creation" of the text is largely ostensible, since, apart from the regulators operating at the societal level, there are internal (self) regulators at the scientific level, and this is where haste, idle talk, lies and chaos cannot be endured. Consequently, everyone who wants to enter this temple not as Caligula and stay in it not as Herostratus, is bound to seek answers to Hamlet's question, checking their choice with the help of Kant's moral imperative [7, p. 98].

\section{References}

1. Про вищу освіту : Закон України від 1 липня 2014p. URL: http://zakon3.rada.gov.ua/laws/show/1556-18/ print1369221587356216.

2. Харитонова О.І., Ульянова Г.О. Академічний плагіат: поняття та наслідки виявлення відповідно до нового Закону України «Про вищу освіту». Часопис цивілістики. 2014. Вип. 17. С. 228-232.

3. Про освіту. Закон України від 05 вересня 2017 р. № 2145-VIII. URL: https://zakon.rada.gov.ua/laws/ show $/ 2145-19$ ?find=1\&text=\%22плагіат\%22\#w11.

4. Code of Ethics. Journal of International Business Studies. URL: http://www.palgrave- journals.com/jibs/jibs_ ethics_code.html.

5. Синченко Г.Ч., Николаенко Н.М. Плагиат - контрплагиат - антиплагиат. Научный вестник Омской академии МВД России. 2013. № 3. С. 49-54.

6. Ульянова Г.О. Методологічні проблеми цивільно-правового захисту прав інтелектуальної власності від плагіату : дис. ... докт. юрид. наук : 12.00.03. 2015. 445 с.

7. Демидова О.Р. Чужое как свое, или Физиология плагиата. Вестник Ленинградского государственного университета им. А.С. Пушкина. 2012. Т. 2. № 3. С. 90-98.

8. Vrielink J., Lemmens P., Parmentier S. Academic freedom as a fundamental right. Advice paper №6. 2010. P. 24.

9. Загальна декларація прав людини від 10 грудня 1948 р. Голос України. 2008. № 236.

10. Рижко О. Рерайт (рерайтинг) як вид плагіату. Записки Львівської національної наукової бібліотеки України імені В. Стефаника. 2015. Вип. 7. С. 467-473.

11. Харитонова Е.И. Гражданские правоотношения интеллектуальной собственности, возникающие в результате творчества (концептуальные основы): монография. Изд. 2-е, перераб. и доп. Одесса : Феникс, 2012. 413 с.

12. Штефан О. Плагіат - невід'ємна частина творчості? Теорія і практика інтелектуальної власності. 2012. № 2. C. 21-23.

13. Березницький $€$. Апропріативне мистецтво, запозичення та авторське право. Сучасне мистецтво. 2005. Вип. 2. URL: http://nbuv.gov.ua/j- pdf/S_ myst_2005_2_28.pdf.

14. Максимова Ю. Appropriation Art: борьба анонимов со звездами. 2009. URL: http://artinvestment.ru/invest/ stories/20090216_appropriation_art.htm

15. Зайцева О. Плагіат чи апропріація у візуальному світі: тонка межа.URL: http://uz.ligazakon.ua/ua/ magazine_article/EA008269.

16. Рассудовский В.А. Заимствование и плагиат в авторском праве. Правоведение. 1979. № 3. С. 54.

Chepys O. I., Candidate of Law, Associate Professor, Associate Professor of the Department of Civil Law and Procedure of the Faculty of Law of the Uzhhorod National University 